\title{
Immunohistochemical, cellular localization and ex- pression of inhibin hormone in the buffalo (Buba- lus bubalis) adenohypophysis at different ages
}

\section{Attia H.F. ${ }^{1^{*}}$, Kandiel M.M. ${ }^{2}$, Ismail T.A. ${ }^{3^{*}}$, Soliman M. M. ${ }^{4^{*}}$, Nassan M. A. ${ }^{5}$, Mansour A. A. ${ }^{6^{*}}$}

Department of Histology and Cytology ${ }^{1}$,Theriogenology ${ }^{2}$ and Biochemistry ${ }^{4}$, Faculty of Veterinary Medicine, Benha University, Egypt. Department of Physiology ${ }^{3}$ and Patholo$\mathrm{gy}^{5}$, Faculty of Veterinary Medicine, Zagazig University, Egypt. Department of Genetics ${ }^{6}$, Faculty of Agriculture, Ain Shams University, Egypt.

*Department of Medical Laboratories and Medical Biotechnology, Faculty of Applied Medical sciences, Taif University, Turabuha branch, KSA.

\section{Abstract}

The pituitary adenohypophysis was obtained from thirty buffaloes-cows, their age's ranges from one month to12 years. Sections of adenohypophysis tissues were immunostained for $\alpha, \beta a$, and $\beta b$ subunits of inhibin hormone. Positive immunostaining specific for the a subunits of inhibin were detected in the cells of the follicles of the adenohypophysis in all ages. Moreover, immunostaining specific for the inhibin $\beta a$ subunits were strong positive at one month, weak positive at 4.5, 8 and 12 years and were negative at 8 months and 1.5 years. However, the immunostaining specific for the inhibin $\beta b$ subunits were positive at one and 8 months, 8 and 12 years and weak positive at 4.5 years and negative at 1.5 year. RT-PCR analysis revealed that both $\alpha$ and $\beta b$ subunits are expressed in all ages except at 1.5 years old animals while $\beta$ a subunit is only expressed at young age.

\section{Key words}

Inhibin, buffalo-cows, Adenohypophysis, RT-PCR, Immunohistochemistry.

\section{Introduction}

There is worldwide interest in buffalo as an animal for meeting the growing demands of meat and milk in developing countries. One of the major breeding problems in buffalos is its low reproductive efficiency. Ovarian cyclicity is regulated by hypothalamic hormones, gonadotro- 
pins and ovarian steroids. Endocrine investigations of the hypothalamo-hypophysial-ovarian axis are needed to gain a better understanding of the reproduction physiology in buffalo and to be able to manipulate reproductive mechanisms to derive the maximum benefit from this animal (Mondal et al., 2007).

They regulate the reproductive system by acting on the pituitary gland and by blocking the synthesis of the FSH- $\beta$ subunit and therefore the secretion of $\mathrm{FSH}$ (Burger and Igarashi, 1988; Attardi et al., 1992; Burger et al., 1998; Knight and Glister, 2001). Inhibin are heterodimeric molecules containing an a subunit and either a $\beta a$ or $\beta b$ subunit, which are connected to each other by a disulfide bond. If the dimer consists of a $\mathrm{Ba}$ subunit the molecule is called inhibin $A$, and if it consists of a $\beta b$ subunit the molecule is called inhibin B (Miyamoto et al., 1985; Robertson et al., 1985; Mason et al., 1986 and Burger and Igarashi, 1988). The three subunits are products of separate genes located on chromosomes 2 ( $\alpha$ and $\beta b$ subunit) and 7 ( $\beta$ a subunit) (Robertson et al., 2004). Inhibins are members of the transforming growth factor $\beta$ (TGF- $\beta$ ) superfamily and are dimeric in structure (Evans and Groome, 2001; Robertson et al., 2004 a,b). Inhibin is a gonadal-derived heterodimeric glycoprotein hormone,

J. Vet. Anat. which selectively inhibits the secretion of follicle stimulating hormone (FSH) from the anterior pituitary gland (Burger, 1988 ; Kandiel et al., 2008). In addition to its action on FSH through hypothalamo-hypophyseal- ovarian axis, inhibin may also plays an important role in regulation of folliculogenesis through autocrine and paracrine control (Findlay, 1993).

Both $\alpha$ - and $\beta$-subunits of inhibin are generated by proteolytic cleavage of two independently synthesized large precursor molecules (Mason et al., 1985, 1986; Forage et al., 1986). In several species, the most predominant form of biologically active inhibin identified has a molecular weight (MW) of approximately 31$32 \mathrm{kDa}$ (Robertson et al., 1985, 1986; Rivier et al., 1985; Fukuda et al., 1986; Miyamoto et al., 1985; Ling et al., 1985). In addition, inhibin of different $\mathrm{MW}$ has been isolated from various species including cattle (Fukuda et al., 1986; Sugino et al., 1992). Two major forms of inhibin (129 and $63 \mathrm{kDa}$ ) with little proteolytic cleavage/processing of the large precursor in the buffalo follicular fluid were determined by (Ganguly et al., 2010). The objectives of this study were to immunolocalize inhibin $\alpha$ and $\square$ ( $\beta$ a and $\beta b$ ) subunits and to investigate the expression of inhibin mRNA in the buffalo-cows adenohypophysis. 


\section{Material and Methods}

\section{Animals and tissues}

Thirty buffaloes-cows (Bubalus bubalis) pituitaries were collected from Al-Amar abattoir in kalyobia governorates, Egypt. Their ages were 1, 8, 18 months $4.5,8$ and 12 years , five animals each. Some animals of the old ages 12 years groups showed silent heat. The samples were preserved in Bouin's fluids, dehydrated in ascending grades of ethanol, cleared in xylene and cut at $3 \mu \mathrm{m}$ for further processing.

\section{Materials}

Rabbit polyclonal antibody against (Tyro30) porcine inhibin a chain (130) $\mathrm{NH} 2$, rabbit anti-cyclic inhibin $\beta$ A (81-113)-NH2 (Code 334-274-ET) and rabbit anti-cyclic inhibin $\beta B$ (80112)-NH2 (Code 305-25-D) were purchased from WAKO Pharmaceutical Company, Tokyo.

\section{Immunohistochemical localiza- tion}

Immunohistochemical staining was generally performed as described by (Mousa and Mousa, 1999). Formalin-fixed and paraffin-embed-ded tissue sections were stained immunohistochemically with antibodies against the alpha and betasubunits of inhibin. Sections were deparaffinized in xylene, rehydrated through graded ethanol, and

washed in phosphate-buffered saline (PBS; $\mathrm{pH}$ 7.4) for two times 10 min each. The sections were then incubated with $0,25 \%(\mathrm{v} / \mathrm{v})$ biotinylated secondary antibody (Vector Laboratories) diluted in PBS containing $10 \%$ normal goat serum to reduce the non specific binding. The sections were then incubated with $2 \%$ avidin-biotin complex. The reaction were visualized with di-amino benzidine tetrahydrochloride (DAB) (Sigma) $0.025 \%$ N 0.05 M PBS. The stained sections were counterstained with Mayer's haematoxyline (Bancroft et al., 1996). After that, the sections were washed in tap water, dehydrated in alcohol, cleared in xylene, and mounted in DPX. Photographed by Leica digital microscopy. Control was performed by exposing section to normal goat serum instead of primary antibodies.

\section{$R T-P C R$ analysis}

All primers were manufactured by BIORON GmbH-Germany. It were designed to have a melting temperature of $60{ }^{\circ} \mathrm{C}$ using the DNASTAR Lasergene version 4.0 expert sequence analysis software and compared with the Genbank using the program BLAST available at www.ncbi.nlm.nih.gov.

Total RNA was extracted from 20 mg of the pituitary gland using QIAGEN RNeasy Mini Kit (50) (Ger- 
many) and tested on denatured agarose gel by electrophoresis. Two micrograms of the total RNA were reverse transcribed into CDNA using Revert Aid First Strand cDNA Synthesis Kit (Fermentas, USA). The reactions were incubated for $60 \mathrm{~min}$ at $420 \mathrm{C}$ and terminated by heating at $70^{\circ} \mathrm{C}$ for $5 \mathrm{~min} .2 \mu \mathrm{l}$ of the cDNA was used for PCR that was carried out in the Perkin Elmer 9600 using a reaction mix containing 1 unit of Ampli Taq Gold (PE Applied Biosystems), $1 \times$ buffer, $1.5 \mathrm{mM} \mathrm{MgCl} 2,2.5$ $\mathrm{mM}$ dNTPs and $20 \mathrm{pmol}$ of each forward and reverse primers for 18S-rDNA (positive control), inhibin $\alpha, \beta a$ or $\beta b$ primers (table 1). The total volume was $50 \mu \mathrm{l}$. An initial cycle of $10 \mathrm{~min}$ at $95^{\circ} \mathrm{C}, 45$ seconds at $55^{\circ} \mathrm{C}$ and 1 minute at $72^{\circ} \mathrm{C}$ was performed. PCR conditions included initial heating at $95^{\circ} \mathrm{C}$ for $5 \mathrm{~min}$ then annealing at $55^{\circ} \mathrm{C}$ for $45 \mathrm{sec}$ and extension at $72^{\circ} \mathrm{C}$ for $1 \mathrm{~min}$ for 35 cycle, followed by final extension at $72^{\circ} \mathrm{C}$ for 7 minutes. A negative control containing RNA instead of $c$ DNA was used to rule out genomic DNA contamination. The PCR products were confirmed by $2 \%$ agarose gel electrophoresis.

A 100 bp DNA ladder molecular weight marker (invitrogen, USA) was used to confirm expected molecular weight of the amplification product (Tabel, 1).

\section{Results}

Positive immunostaining specific for the $\alpha, \beta a$ and $\beta b$ subunits of inhibin were observed in the basophilic cells (Gonadotrophs) of the buffalocows adenohypophysis at one month of age. (Plate.1). Positive immunostaining specific for the $\alpha$ and $\beta b$ subunits and negative immunostaining specific for $\beta a$ were observed in the basophilic cells (Gonadotrophs) of the buffalo-cows adenohypophysis at 8 months. (Plate.2). Positive immunostaining specific for the a subunits and negative immunostaining specific for the $\beta a$ and $\beta b$ subunits in the basophilic cells (Gonadotrophs) of the buffalocows adenohypophysis at 1.5 years old age. (Plate.3). Positive immunostaining specific for the a subunits and weak positive immunostaining specific for the $\beta a$ and $\beta b$ subunit in the basophilic cells (Gonadotrophs) of the buffalo-cows adenohypophysis at 4.5 years. (Plate. 4).

Positive immunostaining specific for the $\alpha$ and $\beta b$ subunits and weak positive immunostaining specific for the $\beta$ a subunit in the basophilic cells (Gonadotrophs) of the buffalo-cows adenohypophysis at 8 and 12 years were observed. (Plate. 5 and 6 respectively). 
Expression of inhibin $\alpha$ and $\beta b$ subunits mRNA were detected in the adenohypophysis of the Egyptian water buffalo Bubalus bubalis at all ages studied relative to internal standard (563 bp) of $18 \mathrm{~S} r$ DNA. Inhibin a band with molecular weight of $217 \mathrm{bp}$ was detected in all animal ages as shown in figure (7) whereas inhibin $\beta a$ band (209 bp) was detected only in the early age (1 month). Expression of inhibin $\mathrm{Ba}$ mRNA was not detected in other ages. The inhibin $\beta b$ band with molecular weight of $218 \mathrm{bp}$ was detected in all ages except at 1.5 years.

\section{Discussion}

Buffalo has recently gained a lot of attention due to its high milk yield with high fat percentage, tolerance to hot and humid climate, lean meat, draught ability and a reasonable growth rate on roughage feeding. Buffalo, as domestic animal with its predominant home tract in South East Asia and Mediterranean, has found great acceptance in the rural economies of Asia and Africa. Some peculiar problems of this species as late maturity, silent heat coupled with poor expression of oestrus, irregular oestrous cyclicity, seasonality in breeding, anoestrus, low conception rate, long postpartum interval and repeat breeding etc. have been the major constraints leading

J. Vet. Anat. to low productivity (Madan et al., 1993; 1996). A considerable attention has been focused in the last two decades on utilizing reproductive endocrinology as a means to identify problems specific to this species and to devise means for augmenting its reproductive performance.

Activin and inhibin were first purified from mammalian follicular fluid as factors that regulate the secretion of follicle-stimulating hormone (FSH) from pituitary cells in culture (Ling et al., 1985, 1986 a,b; Mason et al.,1985; Rivier et al., 1985; Vale et al., 1986). The inhibin is also secreted from extragonadal source such as the pituitary gland and brain (Lau and Li, 1987; Roberts et al., 1989; Schlatt et al., 1991), the placenta (McLachlan et al., 1986), the adrenal, pituitary glands, lung and the spleen (Meunier et al.,1988). It is now clear that activins and their two functional modulators, inhibins and follistatins, control reproductive function by exerting effects on the pituitary as well as throughout the reproductive axis. The endocrine function of inhibins as gonadal feedback modulators of FSH production appears to be more physiologically relevant (De Kretser et al., 2002; Welt et al., 2002 ; Bilezikjian et al.,2004). Expression of the inhibin subunits, in particular the $\beta$-subunits $A$ and $B$, is widespread, and activins 
act as autocrine/paracrine regulators of cell functions in a wide range of tissues, including the gonads, adrenal gland, liver, bone and bone marrow (Vale et al., 1990; Spencer et al., 1992; Centrella et al.,1994; Zhang et al., 1996; De Kretser et al., 2000).

Inhibin is a heterodimeric peptide hormone produced in the ovary that antagonizes activin signaling and FSH synthesis in the pituitary. The inhibin $\beta$-subunit interacts with the activin type II receptor (ActRII) to functionally antagonize activin. The inhibin a-subunit mature domain ( $\mathrm{N}$ terminus) arose relatively early during the evolution of the hormone, and inhibin function is decreased by an antibody directed against the $\alpha$ subunit $\mathrm{N}$-terminal extension region or by deletion of the $\mathrm{N}$-terminal region. The $\alpha$-subunit $\mathrm{N}$-terminal extension region interacts with the activin type I receptor (ALK4) to antagonize activin signaling in the pituitary. (Jie Zhu et al.,2012). The passive immunization of mares against inhibin during the follicular phase of the estrous cycle results in a marked increase in plasma concentrations of $\mathrm{FSH}$ and estradiol-17f3, and in the ovarian follicle population. These data indicate that immune-neutralization of endogenous inhibin enhances a rapid growth of a large number of follicles and results in multiple ovulations in mares,

J. Vet. Anat. largely due to increasing secretion of FSH from the pituitary gland. The control of secretion of FSH by a blockade of inhibin bioactivity may become a new method for controling folliculogenesis and ovulation rate in mares. (Nambo et al., 1998).

Both inhibin $\beta a$ and $\beta b$ subunits were detected in the pituitary gland of buffalo-cows by immunocytochemistry. The immunoreactivity of inhibin $\beta$ b was stronger than that of the inhibin $\beta$ a subunit. The immunoreactivity for inhibin $\beta b$ appears to be localized in close contact with gonadotrophs. (Bilezikjian et al., 2004), these results augmented our findings, that $\beta b$ was stronger in reaction than that of the $\beta a$. The inhibin- $\alpha$ subunits were positive immunostaining in the adenohypophysis cells (Gonadotrophs) at 1, 8,18 months. These results were supported by Terzano (2010) who stated that, plasma Inhibin-A concentrations began to gradually increase four weeks before the onset of puberty $(18,83$ and $13,07 \mathrm{ng} / \mathrm{ml}$, respectively at puberty) and this increase continued throughout the peripuberal period. So, these results imply that inhibin-A can be used as a novel marker of the onset of puberty in buffalo heifers.

In the reproductive system, activins and inhibins have been found to regulate the release of gonadotro- 
phinreleasing hormone (GnRH) from the hypothalamus (Calogero et al., 1998; Peng and Mukai, 2000) and gonadotrophins (GTHs) from the pituitary (Bilezikjian et al., 2001 and Uchiyama et al., 2000).

Inhibin, a suppressor of FSH secretion, is composed of an a chain covalently linked to a $\beta$ chain; whereas activin, a stimulator of FSH secretion, is composed of a dimer of the $\beta$ chain. Since there are two structurally related $\beta$ chains, inhibin has two isoforms (aßA as inhibin $A$, and $a \beta B$ as inhibin $B$ ), and activin has three isoforms $(\beta A \beta A$ as activin $A$, $\beta A \beta B$ as activin $A B$, and $\beta B \beta B$ as activin $B$ ). Expression of both mRNAs for inhibin a and $\beta B$ chains has been demonstrated in the rat pituitary (Meunier et al., 1988; Dalkin et al., 1998).

The importance of inhibins in the control of the reproductive function has been reported (De Kretser et al., 2002; Medan et al., 2007) and it appears that $\beta b$-subunit might be produced in small developing follicles, which is replaced by the inhibin $\beta a$-subunit as the follicles approach the preovulatory stage (Medan et al., 2007). In cattle (Kaneko et al., 2002) and goats (Medan et al., 2005) an inverse relationship between FSH and inhibin-A was demonstrated, suggesting the key role of inhibin-A produced by domi- nant follicle(s) in terminating the transient peaks of $\mathrm{FSH}$ secretion (Medan et al., 2007).

Inhibin is involved in folliculogenesis by negative feedback effects on FSH secretion in buffalo (Mondal et al., 2000b). Peripheral ir-inhibin concentrations were negatively correlated with peripheral progesterone concentrations in buffaloes indicating that corpus luteum is not a source of peripheral inhibin in buffaloes (Mondal et al., 2000a; Mondal et al., 2003a). The peripheral plasma ir-inhibin concentrations were compared between buffaloes which exhibited over oestrus and those which had silent estrus reported that plasma ir-inhibin levels were significantly higher in buffaloes that exhibited silent oestrus indicating that this could be one of the reasons responsible for poor expression of oestrus (Mondal et al., 2002a, b; 2003b).

Inhibin-A may provide an index of follicular development (Lockwood et al., 1996), but studies exploring the relationship between controlled ovarian stimulation, inhibin levels and ovarian follicular development in ruminants are limited (GonzalezBulnes et al., 2002; GonzalezBulnes et al., 2004).

A significant increase in inhibin levels through late luteal to perioestrus 
phase is suggestive of a vital role of inhibin in folliculogenesis (Mondal et al., 2000a; 2001b).

When choosing a semi-quantitative protocol to determine RNA expression levels by RT-PCR, many parameters must be taken into consideration (Freeman et al., 1999). One of these parameters is necessity to study different markers in the same sample. An oligo (dT)18 primer was used instead of gene specific primers in the first strand cDNA formation to synthesize cDNA from the total RNA present in the samples, which will include a common expressed genes (housekeeping genes) like 18S rRNA (Zhou et al., 2010), as well as the investigated target genes (inhibin $\alpha, \beta a$, and $\beta b$ ). This is a very convenient method when a single RNA marker has to be analyzed in a large number of samples. On the other hand, assaying several RNAs on the same sample, we preferred to work on the same cDNA product in order to reduce the variability due to the reverse transcription reaction.

Popovics et al. (2011) examined the regulation of gene expression of $\alpha$, $\beta \mathrm{b}$, and follistatin by local and endocrine hormones $(\mathrm{GnRH})$ in pituitaries from female rats and in perifused pituitary cells by RT-PCR.
The expression of inhibin $\beta b$ was higher than $\beta a$ in the pituitary gland cells, these result was augmented by (Feng et al., 1995; TenaSempere et al., 1999; Toebosch et al., 1988), which stated the Sertoli cell produces two $\beta b$ subunit mRNA transcripts, which are under differential regulation, and normal expression levels of the $\beta b$-subunits appear to be considerably higher than those of the $\beta a$-subunit. inhibin $\beta a$ is actually the predominant form (MacConeilly et al., 2002).

\section{References}

Attardi B, Vaughan J, Vale W (1992): Regulation of FSH beta messenger ribonucleic acid levels in the rat by endogenous inhibin. Endocrinology;130: 557.

Bancroft JD, Stevens A, Turner DR (1996): Theory and practice of histological techniques. 4th ed. London/Toronto: Churchill Livingstone;

Bilezikjian LM, Blount AL, Corrigan $A Z$, Leal $A$, Chen $Y$, Vale WW (2001): Actions of activins, inhibins, and follistatins: implications in anterior pituitary function. Clin. Exp. Pharmacol. Physiol; 28 (3): 244-248.

Bilezikjian Louise M , Amy L Blount, Angela MO Leal, Cindy $\mathrm{J}$ Donaldson, Wolfgang $\mathrm{H}$ 
Fischer, Wylie W Vale (2004): Autocrine/paracrine regulation of pituitary function by activin, inhibin and follistatin. Molecular and Cellular Endocrinology;225:29-36.

Burger HG , Igarashi $M(1988)$ : Inhibin: definition and nomenclature including related substances. Journal of Clinical Endocrinology and Metabolism .; 66: 885-886.

Burger HG (1988): Inhibin: definition and nomenclature, including related substances. Journal of Endocrinology; 117: 159-160.

Burger HG, Groome NP, Robertson DM (1998): Both inhibin A and $B$ respond to exogenous follicle-stimulating hormone in the follicular phase of the human menstrual cycle. J. Clin. Endocrinol. Metab;83: 4167.

Calogero $\mathrm{AE}$, Burrello $\mathrm{N}$, Ossino AM, Polosa PD,_Agata $R$ (1998): Activin-A stimulates hypothalamic gonadotropinreleasing hormone release by the explanted male rat hypothalamus: interaction with inhibin and androgens. J. Endocrinol;156: 269-274.

Centrella M, Horowitz MC, Wozney JM, McCarthy TL(1994): Transforming growth factorbeta gene family members and bone. Endocr. Rev;15: 27-39.
Dalkin A C, Haisenleder D J, Gilrain $\mathrm{J} \mathrm{T}$, Aylor K, Yasin M, Marshall J. C (1998): Regulation of pituitary follistatin and inhibin/activin subunit messenger ribonucleic acids (mRNAs) in male and female rats: Evidence for inhibin regulation of follistatin mRNAin females. Endocrinology;139: 28182823.

De Kretser DM, Hedger MP, Loveland KL, Phillips DJ (2002): Inhibins, activins and follistatin in reproduction. Hum. Reprod. Update;8: 529-541.

De Kretser DM, Meinhardt A, Meehan $\mathrm{T}$, Phillips DJ, O'Bryan MK, Loveland KA (2000): The roles of inhibin and related peptides in gonadal function. Mol. Cell. Endocrinol ;161: 43-46.

Evans LW, Groome NP (2001): Development of immunoassays for inhibin, activin and follistatin. In: Muttukrishna S, Ledger W (Eds.) Inhibin, Activin and Follistatin in Human Reproductive Physiology. Imperial College Press, London; $p: 11$.

Feng ZM, Wu AZ, Chen CL(1995):

Characterization and regulation of two testicular inhibin/activin bB-subunit messenger ribonucleic acids that are transcribed from alternate 
initiation sites. Endocrinology; 136: 947-955.

Findlay JK (1993):An update on the roles of inhibin, activin and follistatin as local regulators of folliculogenesis. Biology of Reproduction; 48: 15-23.

Forage RG, Ring JM, Brown RW, Mclnerney BV, Cobon GS, Gregson, RP,Robertson DM, Morgan FJ, Hearn MTW, Findlay JK, Wettenhall REH, Burger HG, de Kretser DM (1986): Cloning and sequence analysis of cDNA species coding for the two subunits of inhibin from bovine follicular fluid. Proceeding of the National Academy of Sciences, USA; 83: 3091-3095.

Freeman WM, Walker SJ, Vrana KE (1999): Quantitative RTPCR: pitfalls and potential. BioTechniques;26: 112-125

Fukuda M,Miyamoto K, Hasegawa $Y$, Nomura $M$, Igarashi $M$, Kangawa K, Matsuo H (1986): Isolation of bovine follicular fluid inhibin of about 32kDa.Molecular and Cellular Endocrinology;44: 55-60.

Ganguly A , Indrajit Ganguly , Sanat K Meur (2010): Multiple molecular forms of inhibin in buffalo (Bubalus bubalis) ovarian follicular fluid. Research in Veterinary Science; 89:14-19
Gonzales-Bulnes A, SantiagoMoreno J, Garcia-Garcia RM, Souza CJH, Lopez-Sebastian A, Mc Neilly AS (2004): Effect of $\mathrm{GnRH}$ antagonists on gonadotrophin secretion, follicular development and inhibin A secretion in goats. Theriogenology; 61(5):977-985.

Gonzales-Bulnes A ,SantiagoMoreno J, Cocero MJ, Souza CJH, Groome NP, GarciaGarcia RM, Lopez-Sebastian A , Baird TD (2002): Measurement of inhibin $A$ and follicular status predict the response of ewes to superovulatory $\mathrm{FSH}$ treatments. Theriogenology;57:1263-1272.

Jie Zhu S Jack Lin, Chao Zou, Yogeshwar Makanji, Theodore $\mathrm{S}$ Jardetzky, Teresa K Woodruff (2012): Inhibin a-Subunit $\mathrm{N}$-terminus Interacts With Activin Type IB receptor To Disrupt Activin Signaling. The American Society for Biochemistry and Molecular Biology; In press

Kandiel MMM, Watanabe G, Li JY, Manabe N, El-azab Al, Taya $\mathrm{K}(2008)$ : Physiological roles in regulation of $\mathrm{FSH}$ secretion and follicular development during early pregnany in goats. Dom Anim Endocrinology;35:157-163. 
Kaneko H, Noguchi J, Kikuchi K, Todoroki J, Hasegawa $Y$ (2002):Alterations in peripheral concentrations of inhibin $A$ in cattle studied using a timeresolved immunofluorometric assay; Relationship with estradiol and folliclestimulating hormone in various reproductive conditions. Biology of Reproduction; 67:38-45.

Knight PG, Glister C (2001): Potential local regulatory functions of inhibins, activins and follistatin in the ovary. Reproduction;121: 503.

Lau YL, Li C (1987): Localization of cu-inhibin-31 in rodent testis and brain by immunocytochemical procedure and Western blot analysis. Biochem. Biophys. Res. Commun;145: 81-89.

Ling $N$, Ying SY, Ueno $N$, Esch $F$, Denoroy L,Guillemin $R$ (1985):Isolation and partial characterization of aMr 32,000 protein with inhibin activity from porcine follicular fluid. Proc. Natl. Acad.Sci. USA;82: 7217-7221.

Ling N, Ying SY, Ueno N, Shimasaki S, Esch F, Hotta M, Guillemin $\mathrm{R}(1986 a)$ : Pituitary FSH is released by a heterodimer of the beta-subunits from the two forms of inhibin. Nature;321:779-782.
Ling Ying SY, Ueno N, Shimasaki S, Esch F, Hotta M, Guillemin $\mathrm{R}(1986 \mathrm{~b})$ : A homodimer of the beta-subunits of inhibin $A$ stimulates the secretion of pituitary follicle stimulating hormone. Biochem. Biophys. Res. Commun;138: 11291137.

Lockwood G M, Muttukrishna S, Groome N P, Knight P G, Ledger W L (1996):Circulating inhibins and activin $A$ during $\mathrm{GnRH}$-analogue down-regulation and ovarian hyperstimulation with recombinant FSH for in-vitro fertilization- embryo transfer. Clinical Endocrinology;45(6):741-748.

MacConell LA, Leal AM, Vale WW(2002): The distribution of beta glycan protein and mRNA in rat brain, pituitary, and gonads: implications for a role for betaglycan in inhibinmediated reproductive functions. Endocrinology;143: 1066-1075.

Madan M L, Das S K, Palta P (1996):Application of reproductive technology to buffaloes. Anim. Reprod. Sci ; 42 : 299-306.

Madan M L, Prakash B S, Jailkhani $S$, Singla S K, Palta $P$, Manik R S (1993): Buffalo endocrinology with special reference to embryo transfer. Embryo 
Biotechnology Centre, NDRI,

Karnal, India; pp :32.

Mason A J, Hayflick J S, Ling N, Esch $F$, Ueno $N$, Ying SY,Guillemin R, Niall $H$, Seeburg $\mathrm{P} \mathrm{H}$ (1985): Complementary DNA sequences of ovarian follicular fluid inhibin show precursor structure and homology with transforming growth factor-beta. Nature; 318: 659-663.

Mason AJ, Niall HD, Seeburg PH (1986): Structure of two human ovarian inhibins. Biochem. Biophys. Res. Commun;135: 957.

McLachlan RI, Healy DL, Robertson DM, Burger HG, de Kretser DM (1986):The human placenta: a novel source of inhibin. Biochem. Biophys. Res. Commun;140: 485-490.

Medan MS, Arai KY, Watanabe G, Taya K (2007): Inhibin: Regulation of reproductive function and practical use in females. Animal Science Journal; 78:16-27.

Medan MS, Watanabe G, Sasaki K, Groome NP, Sharawy S, Taya K (2005): Follicular and hormonal dynamics during the estrous cycle in goats. Journal of Reproduction and Development;51: 455-463.

Meunier H, Rivier C, Evans R M, Vale W (1988): Gonadal and extragonadal expression of inhibin $a, b A$ and bB subunits in various tissues predicts diverse functions. Proc. Natl. Acad. Sci. USA;85: 247-251.

Miyamoto K, Hasegawa Y, Fukuda $M$, Nomura $M$, Igarashi $M$, Kangawa K, Matsuo H (1985): Isolation of porcine follicular fluid inhibin of $32 \mathrm{KD}$ altons. Biochem. Biophys. Res. Commun;129: 396.

Mondal S, Prakash B S, Palta $P(2000 b)$ : Relationship between peripheral plasma inhibin and FSH in cycling Murrah buffaloes (Bubalus bubalis). J. Endocrinol. (Supp.); 167:67 (Abstr.)

Mondal S, Prakash B S, Palta P (2001b): Comparison of changes in peripheral plasma inhibin in relation to oestrous cycle between cows and buffaloes. In: Proceed. Br. Soc. Anim. Sci., London, UK; p: 221.

Mondal S, Prakash B S, Palta $\mathrm{P}(2003 a)$ : Relationship between peripheral plasma inhibin and progesterone concentrations in Sahiwal cattle (Bos indicus) and Murrah buffaloes (Bubalus bubalis). Asian-Aust. J. Anim. Sci; 16 (1): 6-10.

Mondal S, Prakash B S, Palta $P(2003 b)$ : Peripheral plasma 
inhibin concentrations in relation to expression of oestrus in Murrah buffaloes (Bubalus bubalis). Ind. J. Anim. Sci ;73 (4):405-407.

Mondal S, Palta P, Prakash B $S(2000 a)$ : Peripheral inhibin concentrations in relation to stage of oestrous cycle and progesterone in Sahiwal cows and Murrah buffaloes. In: Proceedings of 14th International Congress on Animal Reproduction, Stockholm, Sweden; $1: 209$.

Mondal S, Palta P, Prakash B S (2002a): Peripheral plasma inhibin concentrations in relation to overt and silent oestrus in Sahiwal cows and Murrah buffaloes. Biol. Reprod; (Supp 1) $66: 261$ (Abstr.).

Mondal S, Palta P , Prakash B S (2002b): Peripheral plasma inhibin concentration in relation to oestrus expression in Murrah buffaloes. In: Proceedings of 89th Session of Indian Science Congress Association, Lucknow, India; p: 64-65.

Mondal S , Prakash B S, Palta $P(2007)$ : Endocrine Aspects of Oestrous Cycle in Buffaloes (Bubalus bubalis): An Overview. Asian-Aust. J. Anim. Sci ;Vol. 20, No. 1 : 124 - 131.

Mousa MA, Mousa SA ( 1999): Immunocytochemical study on the localization and distribution of the somatolactin cells in the pituitary gland and the brain of Oreochromis niloticus (Teleostei, Cichlidae). Gen. Comp. Endocrinol.;113: 197211.

Nambo Y, Kaneko H, Nagata S, Oikawa M T Yoshihara, Nagamine $\mathrm{N}$, Watanabe $\mathrm{G} \mathrm{K}$ (1998): Effect of passive immunization against inhibin on FSH secretion, folliculogenesis and ovulation rate during the follicular phase of the estrus cycle in mares. Theriogenology.; 50:545-557.

Peng C, Mukai ST (2000): Activins and their receptors in female reproduction. Biochem. Cell Biol.;78 (3): 261-279.

Popovics P, Rekasi Z, Stewart AJ, Kovacs M (2011): Regulation of pituitary inhibin/activin subunits and follistain gene expression by $\mathrm{GnRH}$ in female rats. J. Endocrinol;210(1): 719 Apr. 13.

Rivier J, Spiess J, McClintock R, Vaughan J, Vale W (1985): Purification and partial characterization of inhibin from porcine follicular fluid. Biochem. Biophys. Res. Commun;133: 120-127.

Roberts V, Meunier H, Vaughan J, Rivier J, Rivier C, Vale W, Cawchenko P (1989): Produc- 
tion and regulation of inhibin subunits in pituitary gonadotropes. Endocrinology;124: 552-554.

Robertson DM, Burger HG, Fuller PJ (2004a): Inhibin/activin and ovarian cancer. Endocr. Relat. Cancer ;11: 35.

Robertson DM, de Vos FL, Foulds LM, McLachlan RI, Burger HG, Morgan FJ, Hearn MTW, de Kretser DM (1986): Isolation of a $31 \mathrm{kDa}$ form of inhibin from bovine follicular fluid. Molecular and Cellular Endocrinology;44: 271-277.

Robertson DM, Foulds LM, Leversha L,Morgan FJ, Hearn MT, Burger HG, Wettenhall RE, de Kretser D M (1985):Isolation of inhibin from bovine follicular fluid. Biochem. Biophys. Res. Commun;126: 220.

Robertson DM, Pruysers E, Burger $H G$, Jobling $T$, McNeilage $\mathrm{J}$, Healy D(2004b): Inhibins and ovarian cancer. Mol. Cell. Endocrinol ;225: 65.

Schlatt S, Weinbauer GF, Nieschag

E (1991): Inhibin-like gonadotrophin-like immunoreactivity in pituitary cells of male monkeys, Macaca fascicularis, Macaca mulatta. Cel1 Tissue Res.; 265: 203-209.

Spencer SJ, Rabinovici J, Mesiano

S, Goldsmith PC, Jaffe $\mathrm{RB}$ (1992): Activin and inhibin in the human adrenal gland. Regulation and differential effects in fetal and adult cells. J. Clin. Investig;90: 142-149.

Sugino K, Naka Mura T, Takio K, Miya Moto K, Hasegawa $\mathrm{Y}$, Igarashi $\mathrm{M}$, Titani $\mathrm{K}$, Sugino $\mathrm{H}$ (1992): Purification and characterization of high molecular weight forms of inhibin from bovine follicular fluid. Endocrinology;130: 789-796.

Tena-Sempere M, Kero J, Rannikko A, Yan W, Huhtaniemi I(1999): The pattern of inhibin/activin a- and bB-subunit messenger ribonucleic acid expression in rat testis after selective Leydig cell destruction by ethylene dimethane sulfonate. Endocrinology; 140: 5761-5770.

Terzano GM (2010): Inhibin A: experience and role in buffalo reproductive physiology.Rev. Vet. 21, Sup 1: 172-178.SAS, 2006. The SAS System for Windows, Release 9.2. SAS Institute Inc., Cary, NC, USA

Toebosch AM, Robertson DM, Trapman J, Klaassen $\mathrm{P}$, de Paus RA, de Jong $\mathrm{FH}$, Grootegoed JA(1988): Effects of FSH and IGF-I on immature rat Sertoli cells: inhibin a- and b-subunit mRNA levels and inhibin secretion. Mol. Cell. Endocrinol;55: 101-105. 
Uchiyama H, Koda A, Komazaki S, Oyama M, Kikuyama S(2000): Occurrence of immunoreactive avtivin/inhibin beta(B) in thyrotrophs and gonadotrops in the bullfrog pituitary: possible paracrine/autocrine effects of activin B on gonadotropin secretion. Gen. Comp. Endocrinol;118: 68-76.

Vale W, Rivier J, Vaughan J, McClintock R, Corrigan A, Woo W, Karr D, Spiess J. (1986):Purification and characterization of an FSH releasing protein from porcine ovarian follicular fluid. Nature;321: 776-779.

Vale WW, Hseuh A, Rivier, C, Yu J (1990): The inhibin/activin family of hormones and growth factors. In: Sporn, M.A., Roberts, A.B. (Eds.), Peptide growth factors and their receptors. Handbook of
Experimental Pharmacology; vol 95. Springer, Berlin, pp: 211-248.

Welt C, Sidis $Y$, Keutmann $H$, Schneyer A (2002): Activins, inhibins, and follistatins: from endocrinology to signaling: a paradigm for the new millennium. Exp. Biol. Med Maywood;227: 724- 752.

Zhang $Y Q$, Kanzaki M, Mashima $\mathrm{H}$, Mine T, Kojima I(1996): Characterization of the activin receptor in cultured rat hepatocytes. Hepatology.; 24: 446450.

Zhou RX, Meng T, Meng, H B , Cheng DX (2010): Selection of reference gene in transcription analysis of gene expression of the mandarin fish, Siniperca chuasti. Zoological Research ; 31(2): 141-146.

\section{Corresponding author:}

Hossam Fouad Attia, Department of Histology and Cytology, Faculty of Veterinary Medicine, Benha University, Egypt. drhossam222@hotmail.com 

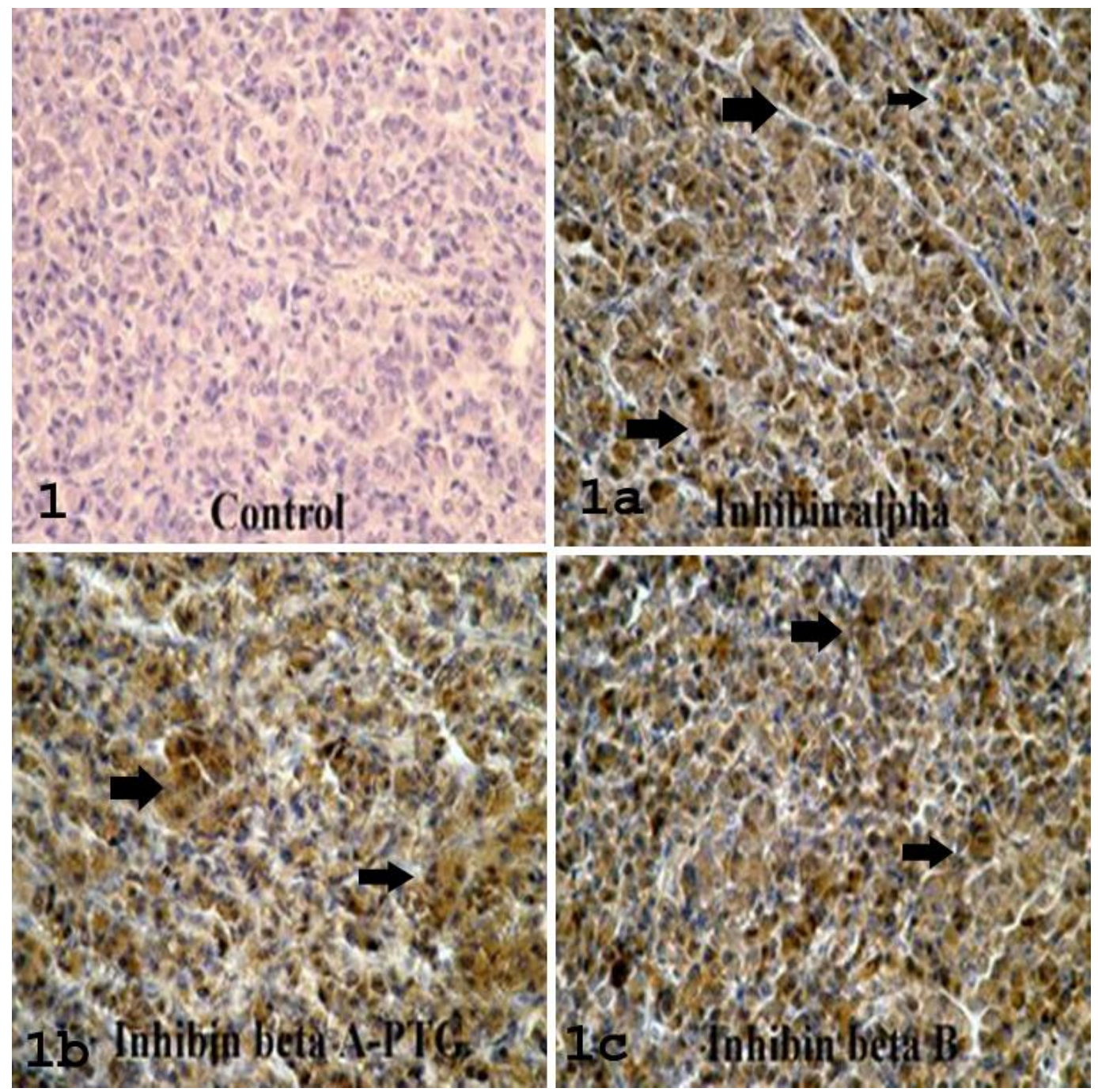

Plate (1): Photomicrograph of the buffalo-cows adenohypophysis at 1 month showing, control immunostaining (1), positive immunostaining specific for the inhibin a (1a) arrows, $\beta a(1 b)$ and $\beta b(1 c)$ subunits (arrows). $X 100$ 

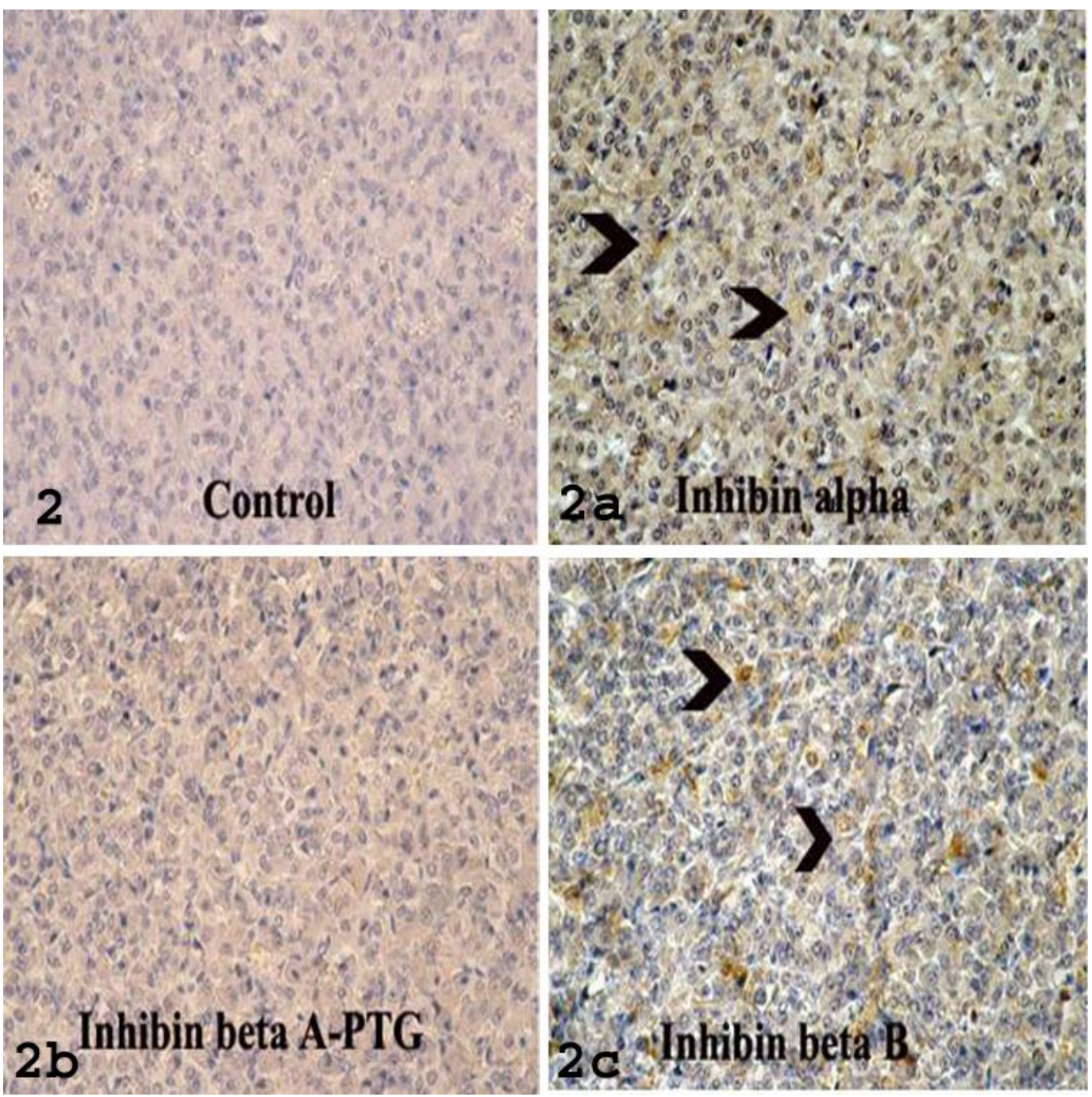

Plate (2): Photomicrograph of the buffalo-cows adenohypophysis at 8 months showing, control immunostaining (2), positive immunostaining specific for the inhibin $\alpha(2 a), \beta b$ (2c) and negative immunostaining $\beta a(2 b)$ subunits (arrow heads) . X100 

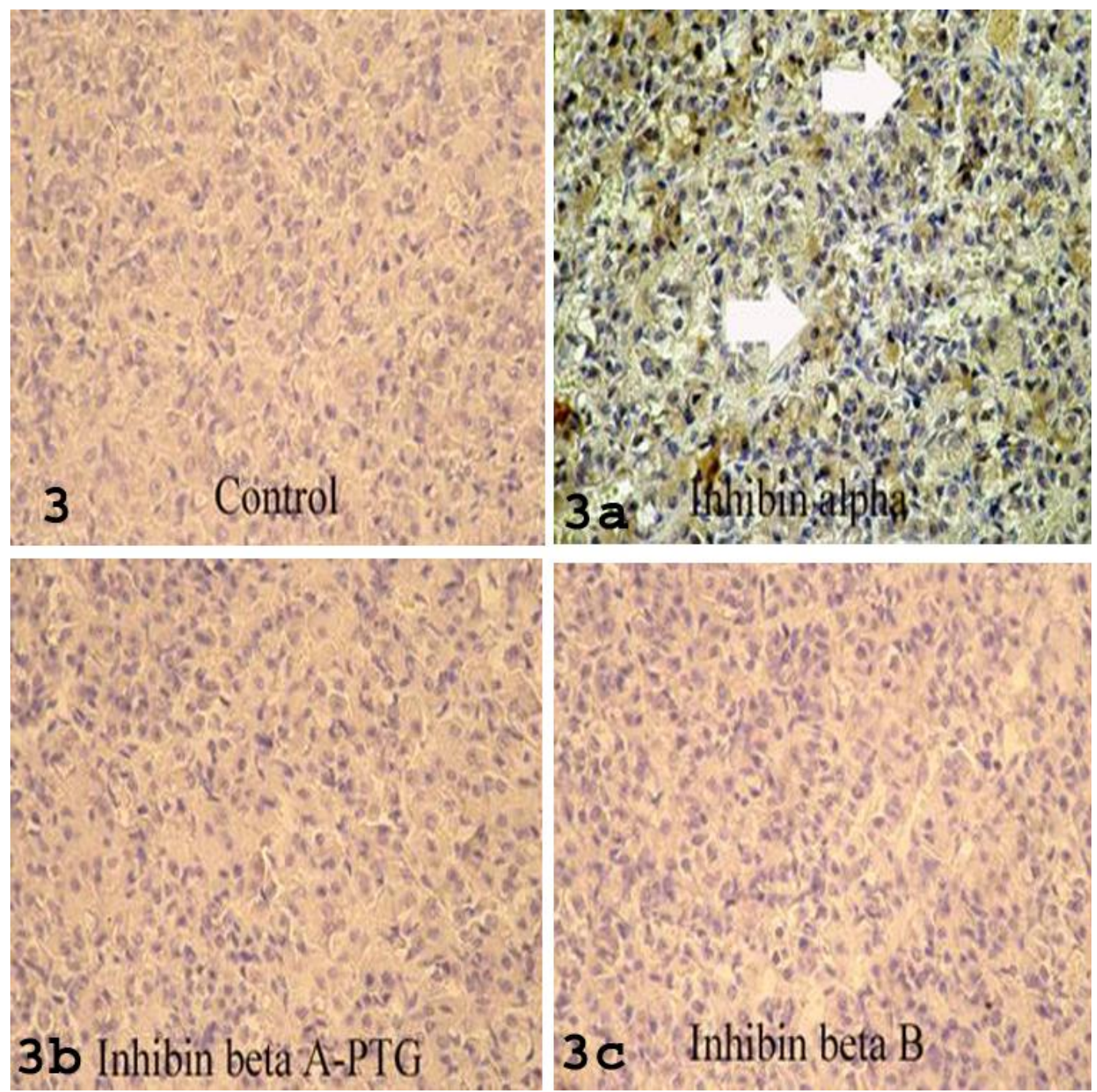

Plate (3): Photomicrograph of the buffalo-cows adenohypophysis at 1.5 years showing, control immunostaining (3), positive immunostaining specific for the inhibin $\alpha(3 a)$, and negative immunostaining for $\beta a(3 b)$ and $\beta b(3 c)$ subunits (arrows).. X100 

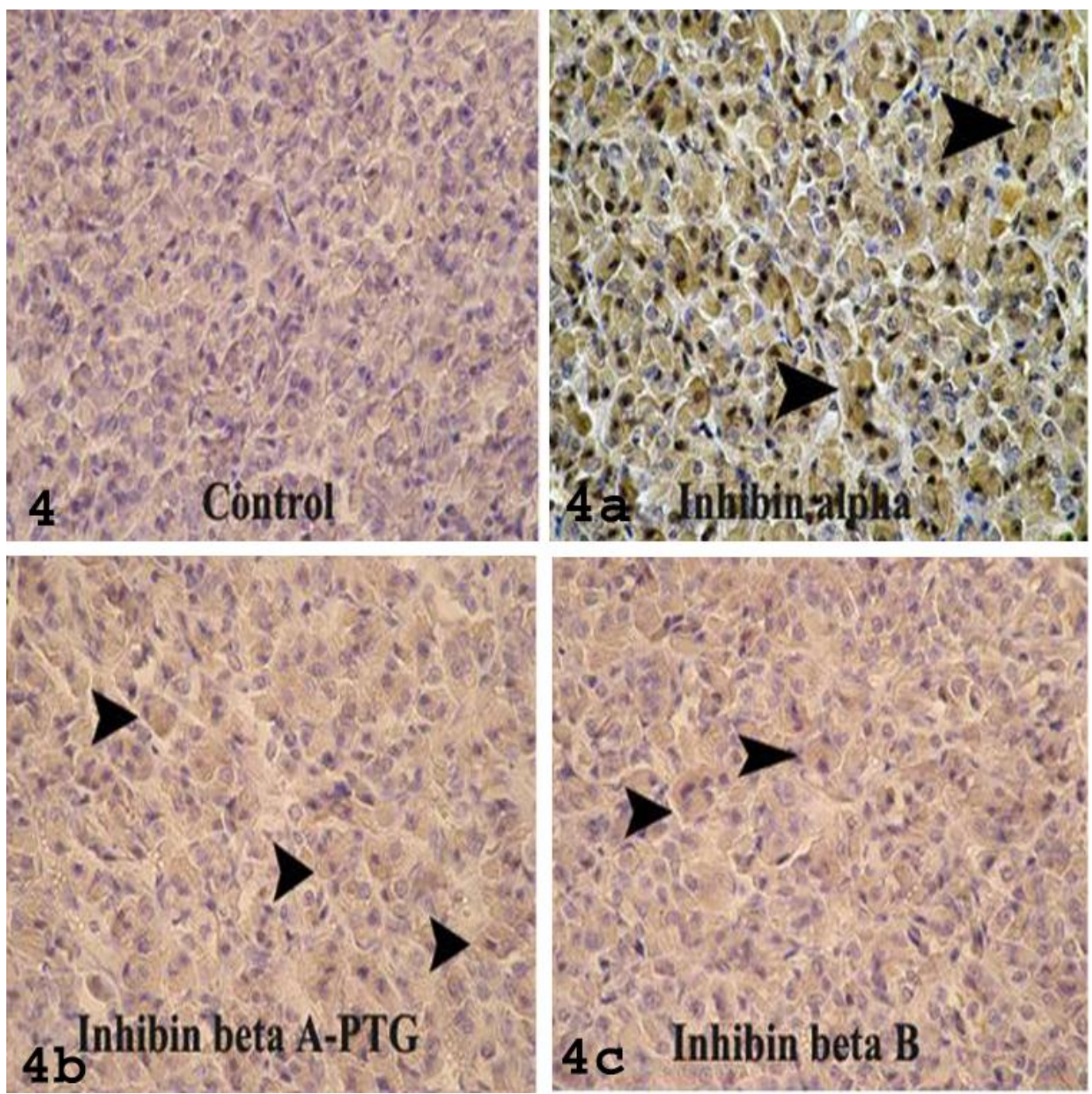

Plate (4): Photomicrograph of the buffalo-cows adenohypophysis at 4.5 years showing, control immunostaining (4), positive immunostaining specific for the inhibin $\alpha(4 a)$, and weak positive immunostaining for $\beta a(4 b)$ and $\beta b(4 c)$ subunits (arrow heads). X400 

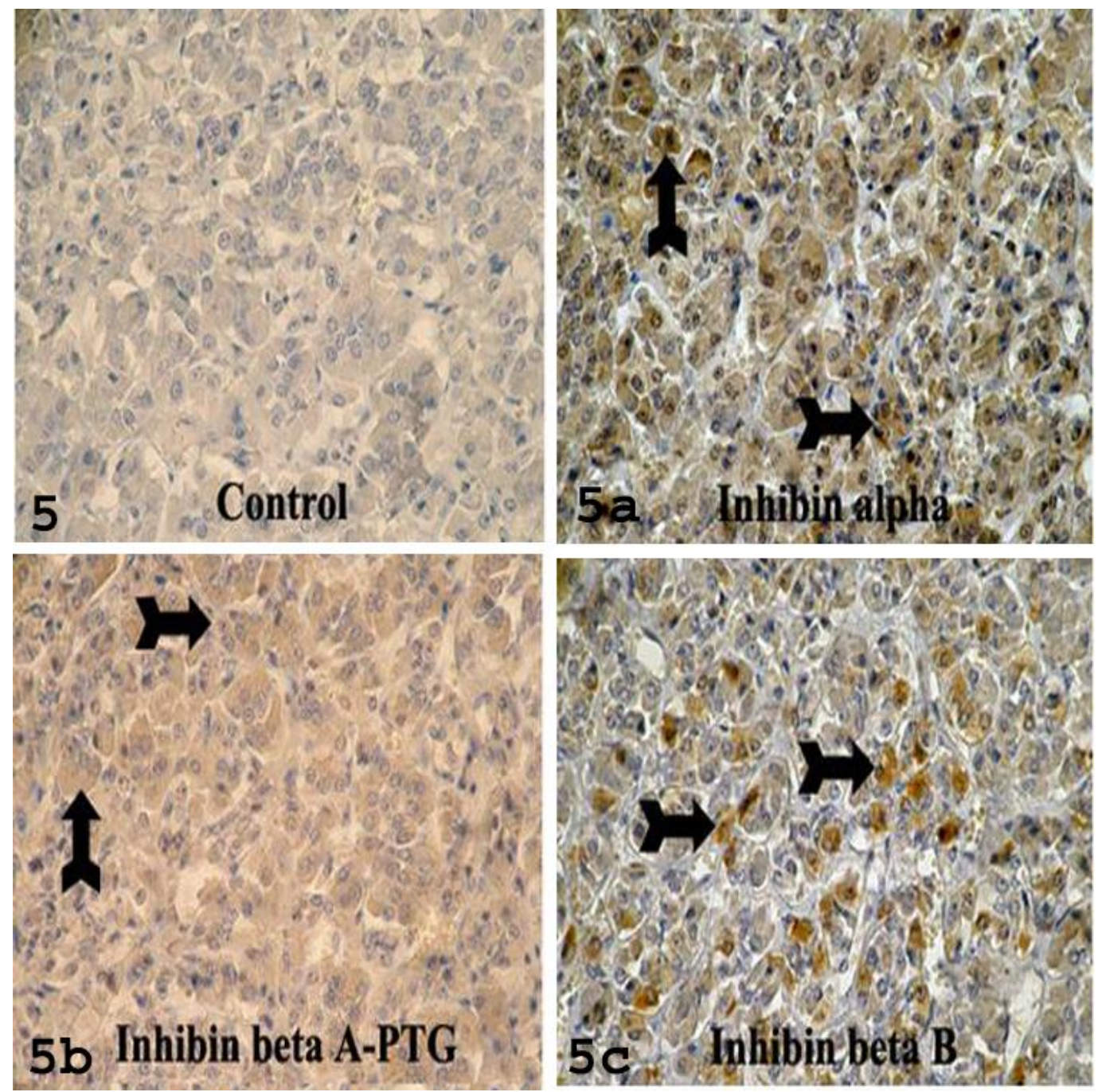

Plate (5): Photomicrograph of the buffalo-cows adenohypophysis at 8 years showing, control immunostaining (5), positive immunostaining specific for the inhibin $\alpha(5 a)$, and $\beta b(5 c)$ and weak positive immunostaining for $\beta a(5 b)$ and subunits(arrows). X400 

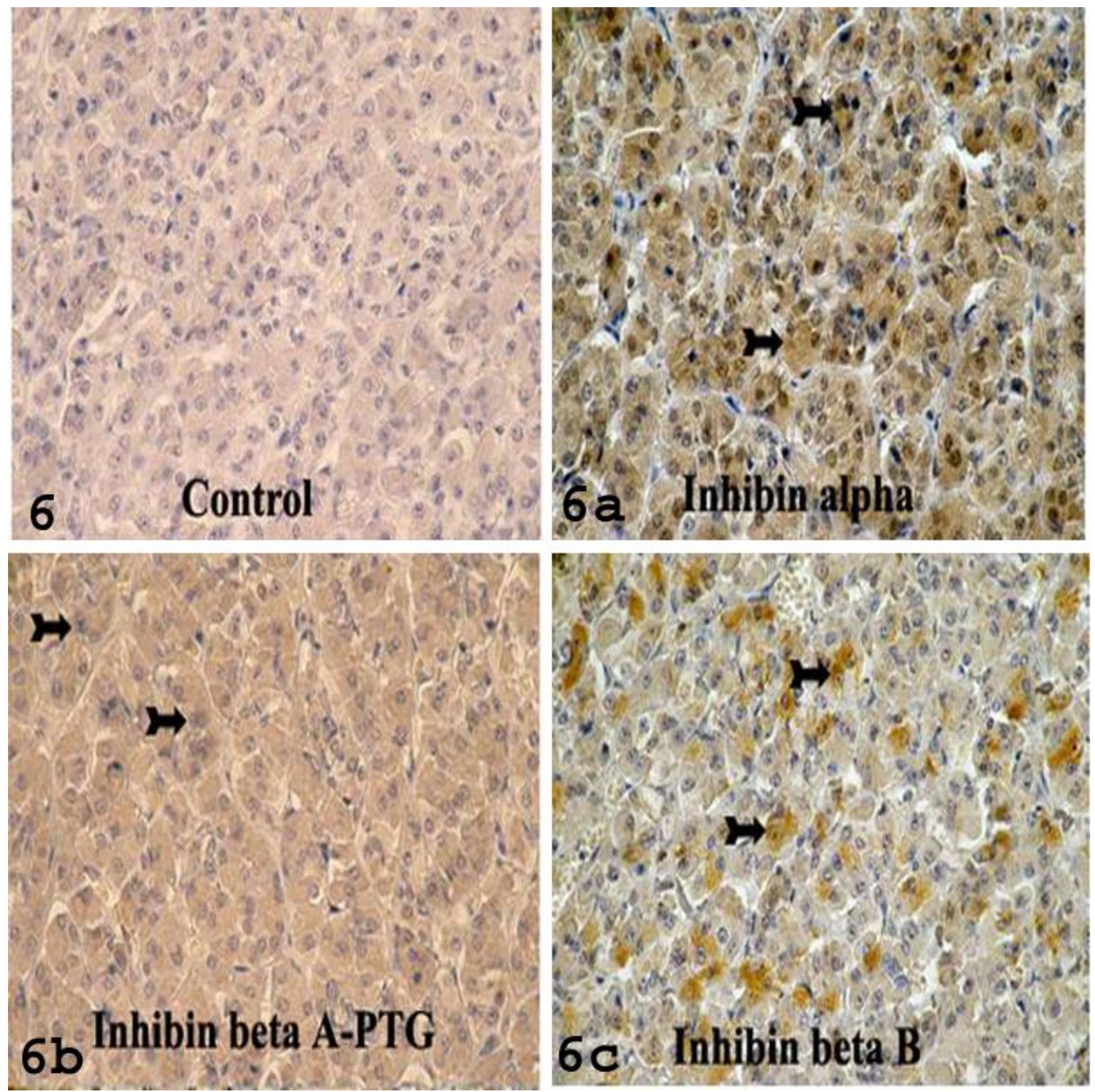

Plate (6): Photomicrograph of the buffalo-cows adenohypophysis at 12 years showing, control immunostaining (6), positive immunostaining specific for the inhibin $\alpha(6 a), \beta b$ $(6 c)$ and weak positive immunostaining for $\beta a(6 b)$ subunits (arrows). X400 


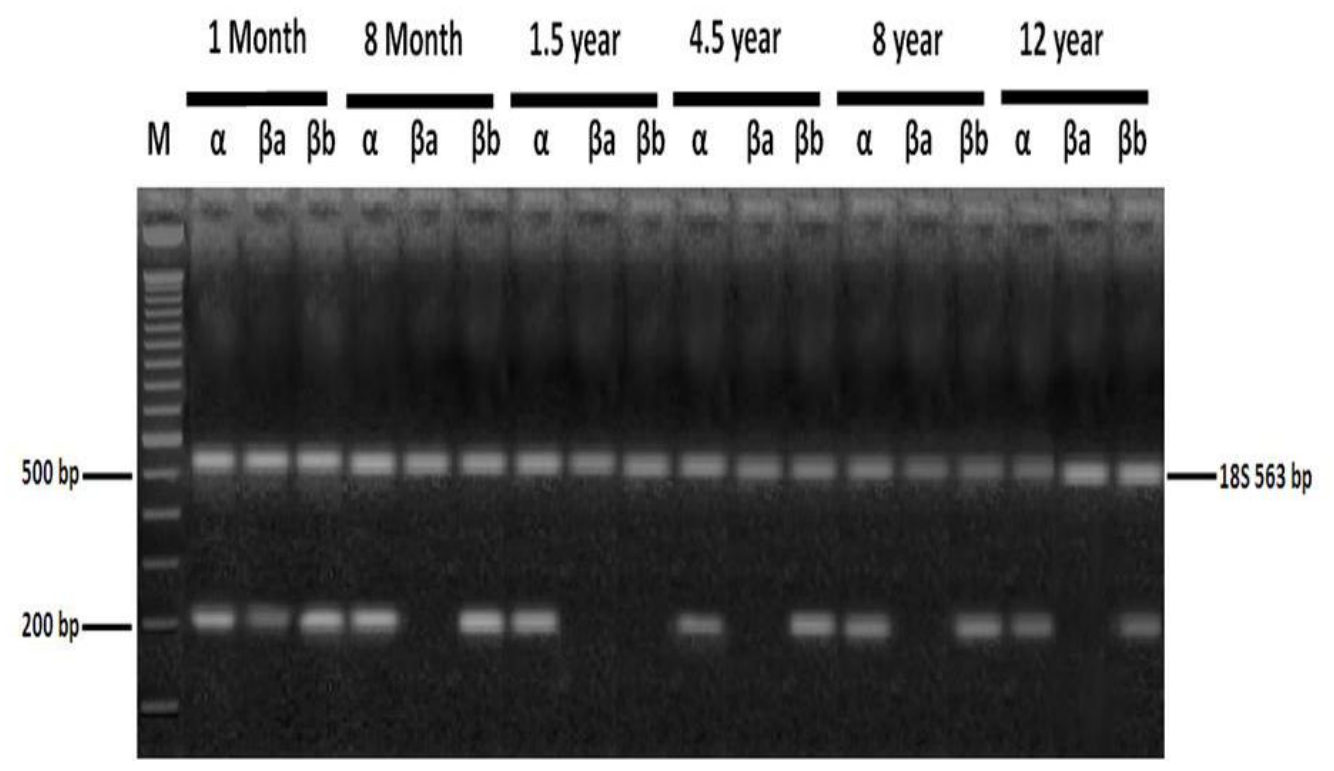

Figure (7): PCR products of 18S r RNA ( 563 b p), 217 bp of inhibin $\alpha, 209$ bp of inhibin $\beta a$, and 218 bp of inhibin $\beta b$ of six ages of Egyptian buffalo Bubalus bubalis $L$ run on $2 \%$ agarose gel electrophoresis. (M) 100 bp DNA ladder.

Table (1): Primers sequence and product size of tested genes.

\begin{tabular}{|c|c|c|}
\hline Primer name & Sequence & $\begin{array}{c}\text { Expected PCF } \\
\text { product } \\
\end{array}$ \\
\hline $\begin{array}{l}\text { 18S-rDNA(F) } \\
18 s-r D N A(R) \\
\text { In- } \alpha(F) \\
\text { In- } \alpha(R) \\
\text { In- } \beta a(F) \\
\text { In- } \beta a(R) \\
\text { In- } \beta b(F) \\
\text { In- } \beta b(R)\end{array}$ & $\begin{array}{l}\text { 5'-CCGGCGGCTTTGGTGACTC-3' } \\
\text { 5'-GCTCGGGCCTGCTTTGAACA3' } \\
\text { 5'- GGGACTGGACAGACAGGAG3' } \\
\text { 5'-GGTGGAGCAGGAACAGAGAG-3' } \\
\text { 5'-GGAAGGGAAGAAGAGGGATG-3' } \\
\text { 5'-AGTCATTCCAGCCAATGTCC-3' } \\
\text { 5'-GCTGGAACGACTGGATCATT-3' } \\
\text { 5'-CTCGTCGTCGAAGTAGAGCA-3' }\end{array}$ & $\begin{array}{l}217 \text { bp } \\
209 \text { bp }\end{array}$ \\
\hline
\end{tabular}

